\section{AS CATEGORIAS DO SUJEITO NA CONTEMPORANEIDADE}

O sujeito na contemporaneidade, de Joel Birman. Rio de Janeiro: Civilização Brasileira, 2012, 159 p.

\footnotetext{
Isabel Fortes

Professora colaboradora do Programa de Pós-Graduação em Teoria Psicanalítica da UFRJ. Professora da Pós-Graduação em Psicanálise, Saúde e Sociedade da Universidade Veiga de Almeida/RJ.
}

O livro O sujeito na contemporaneidade analisa o modo como as transformações que vêm ocorrendo em todos os níveis sociais incidem no registro estrito do sujeito, buscando apreender as novas formas de mal-estar que o acometem.

Muitos autores dos campos da psicanálise e da antropologia sustentam uma diferença crucial entre o campo social da atualidade com o que ocorria há algumas décadas no que concerne tanto ao coletivo quanto ao indivíduo. O próprio Joel Birman publicou, em 1999, o livro Mal-estar na atualidade: a psicanálise e as novas formas de subjetivação (Rio de Janeiro: Civilização Brasileira), um extenso e brilhante diagnóstico dos traços que definiriam a subjetividade na cultura da atualidade.

A ideia geral desses estudos é a de que as novas modalidades de mal-estar teriam começado a indicar a sua diferença há algumas décadas, tomando o lugar das antigas formas de sofrimento. Na modernidade - período que iria do século XIX até meados do século XX —, a subjetividade era regulada pelo conflito psíquico, que indicava uma oposição entre as pulsões e as interdições morais. Já os tempos atuais seriam regidos por formas diferentes de regulação social, nas quais imperam a exigência da performance e da iniciativa individual. Em vez da interdição, observase hoje uma incitação à ação.

Mas a originalidade do livro em pauta reside, justamente, na proposta de demarcar as categorias que constituem o sujeito. As transformações que se revelam no campo social encontram ressonâncias em elementos psíquicos fundamentais que tecem a estruturação do sujeito. Dessa maneira, os dez capítulos que o compõem examinam o modo como, na subjetividade atual, a categoria de espaço teria substituído a dimensão da temporalização e, intimamente ligado a isso, o fato de que a dor tem sido, às expensas do sofrimento, a marca dos padecimentos atuais. Apesar de serem frequentemente vistas como sinônimos, essas duas experiências são descritas de formas diferenciadas — enquanto na dor o sujeito fica entregue ao excesso que o acossa, no sofrimento há a presença do outro, justamente com uma função apaziguadora face ao excesso. Paralelamente a isso, observa-se que o sujeito se defronta cada vez mais com a experiência do desalento, em que o domínio do pesadelo toma o lugar da dimensão do sonho.

Com efeito, o primeiro capítulo do livro desenvolve a tese de que a potência do sonho teria sido atingida pela supremacia do pesadelo. Segundo o autor, a capacidade 
de sonhar encontra-se desvitalizada, na medida em que se esvazia a dimensão do desejo e entram em cena os registros da dor e do trauma. A experiência do sonhar configura processos de simbolização cuja condição de possibilidade é a temporalidade. Já no pesadelo, assistimos a um curto-circuito da elaboração onírica, pois o trauma que o constitui carreia o susto, o horror e a surpresa, fazendo irromper o inesperado, aquilo para o qual o psiquismo não estava preparado. Trata-se de uma experiência de angústia que leva o sujeito a despertar de maneira abrupta e assustada, retirando-o da proteção que experimenta quando acalentado pela elaboração onírica e pela capacidade de sonhar.

Nos capítulos seguintes, o autor desenvolve uma proposta bastante original, ao dizer que o sujeito atual estaria inscrito muito mais na ordem do espaço do que no registro do tempo. As relações entre as categorias do espaço e do tempo fornecem indicações importantes acerca da estruturação do sujeito. A espacialização da experiência subjetiva estaria circunscrita à hegemonia do olhar, do espetáculo, da exibição e da exacerbação da dimensão da imagem. A inflação da imagem e a presença maciça do narcisismo trazem miragens de um eterno presente, marcado pela repetição do mesmo, apagando a temporalização e, a reboque, todo horizonte de futuro. Vive-se uma era da pressa e da aceleração que abole em uma só tacada o tempo, o futuro e o desejo, já que este último tem como condição a inscrição psíquica dos dois primeiros. A espacialização revela um sujeito não mais interiorizado na ordem do pensamento, mas o ser exteriorizado e performático que traz consigo a marca do excesso que impele para a ação e se manifesta no domínio do corpo.

Assim, a subjetividade se confronta com a experiência do desalento, que lan- ça o sujeito no abismo do solipsismo, da solidão e do vazio afetivo, sem qualquer oportunidade de interlocução, sendo-lhe subtraída a possibilidade de fazer apelo ao outro. De maneira diferente do desamparo, que permite ao sujeito o exercício de demandar ao outro e, desse modo, estabelecer trocas afetivas e produzir sentidos para a sua vida, o desalento é marcado pela aridez da alteridade, da presença do outro como suporte do psiquismo.

Todos estes elementos teóricos servem como sustentação conceitual do programa do livro: delinear as condições do sujeito na atualidade por meio da captação de suas modalidades de mal-estar. Como já dito aqui, a precariedade da dimensão alteritária faz com que os padecimentos do sujeito na contemporaneidade se expressem como dor e não como sofrimento. A dor que acomete a subjetividade atual não encontra este destinatário e produz padecimentos que se manifestam pelas somatizações, pelas compulsões, pela despossessão de si e pelo vazio no existir.

A indagação fundamental que atua como pano de fundo e permeia todo o livro - interrogação que certamente interpelará os leitores psicanalistas —, é a de como situar a psicanálise nesse quadro, ou, em outras palavras, como ela irá tratar e acolher este sujeito que se forja a partir de tais inéditas e surpreendentes categorias.

Recebido em 14/8/2013.

Aprovado em 6/9/2013.

Isabel Fortes

mariaisabelfortes@gmail.com 